\title{
MODEL PEMBELAJARAN CREATIVE PROBLEM SOLVING (CPS) UNTUK MENINGKATKAN KREATIVITAS ILMIAH DAN HASIL BELAJAR MATERI LARUTAN PENYANGGA
}

\section{Creative Problem Solving (Cps) Learning Models To Improving Scientific Creativity And Learning Results Material Of Buffer Solution}

Jalimah Dahlena*, Abdul Hamid, Muhammad Kusasi

Program Studi Pendidikan Kimia FKIP Universitas Lambung Mangkurat, Jl. Brigjen H. Hasan Basry Banjarmasin 70123 Kalimantan Selatan Indonesia *email: jalimahdahlena123@gmail.com

\begin{abstract}
Abstrak. Telah dilakukan penelitian tindakan kelas yang bertujuan untuk meningkatkan (1) Aktivitas guru, (2) Aktivitas peserta didik, (3) Kreativitas ilmiah dan (4) Hasil belajar peserta didik. XI MIPA 2 SMAN 8 Banjarmasin adalah subjek penelitian ini. Adapun hasil dari penelitian yaitu: (1) Dalam pelaksanaan tindakan aktivitas guru mengalami peningkatan dari kategori cukup baik menjadi kategori baik, (2) Aktivitas peserta didik yang awal mulanya kategori cukup aktif menjadi kategori aktif, (3) Kreativitas ilmiah peserta didik dengan kriteria baik yang awalnya cukup, (4) Hasil siklus I pengetahuan berada dikategori rendahdan terjadi peningkatan menjadi baik, sikap peserta didik mengalami peningkatan yang awal mulanya cukup aktif menjadi aktif dan keterampilan yang awal mulanya cukup terampil berubah menjadi terampil. Berdasarkan hasil penelitian maka dapat diketahui bahwa model pembelajaran Creative Problem Solving (CPS) ini dapat meningkatkan kreativitas ilmiah dan hasil belajar peserta didik pada materri larutann penyangga.
\end{abstract}

Kata kunci: kreativitas ilmiah, hasil belajar, Creative Problem Solving, larutan penyangga.

\begin{abstract}
Class action research has been conducted which aims to improve (1) Teacher activity, (2) Student activity, (3) Scientific creativity and (4) Student learning outcomes. XI MIPA 2 SMAN 8 Banjarmasin is the subject of this research. The results of the study are: (1) In the implementation of the activities of teacher activity has increased from quite good categories to good categories, (2) Student activities that were initially quite active categories become active categories, (3) Scientific creativity of students with good criteria which was initially sufficient, (4) The results of the first cycle of knowledge were in the low category and there was an increase in being good, the attitude of the students experienced an increase that was initially quite active to be active and the skills that were initially quite skilled turned into skilled. Based on the results of the study it can be seen that the Creative Problem Solving (CPS) learning model can improve scientific creativity and student learning outcomes in buffering material.
\end{abstract}

Keywords: Scientific creativity; learning result; Creative Problem Solving; buffer solution

\section{PENDAHULUAN}

Ilmu yang mempelajari tentang materi serta perubahannya disebut ilmu kimia dan tak jarang dikatakan sebagai "central of science" (Susilowati \& Harjani, 2013). Salah satu mata pelajaran yaang wajib di lingkungan pendidikan khususnya kelas sains adalah ilmu kimia. Pembelajaran ilmu kimia sering dipandang sebagai suatu

Copyright $\odot$ JCAE-Jurnal Tugas Akhir Mahasiswa, e-ISSN 2613-9782

Program Studi Pendidikan Kimia FKIP Universitas Lambung Mangkurat 
konsep materi yang rumit untuk dipahami sehingga minat dan keinginan mereka untuk belajar kimia menjadi hilang (Ristiyani \& Bahriah, 2016).

Data hasil pengetahuan ujian SMA sederajat di Banjarmasin tahun 2016/2017 yang didapatkan melalui aplikasi Pengoperasian Aplikasi Laporan Pemanfaatan Hasil Ujian Nasional (PAMER), daya serap di SMAN 8 Banjarmasin pada materi larutan penyangga masih tergolong rendah, yaitu hanya $41,18 \%$ dalam sekolah, $60,41 \%$ antarkota Banjarmasin, 53,32\% antarprovinsi dan 44,24\% dalam skala nasional.

Penggunaan model Creative Problem Solving (CPS) dipilih untuk mengatasi permasalahan yang ada di SMAN 8 Banjarmasin. CPS merupakan keterampilan pemecahan masalah (Syamsu, Yunus, \& Masri, 2016). Penelitian Hartantia, Hayus, \& Saputro (2013) menyebutkan model pembelajaran CPS dapat menimbulkan minat, kreativitas, dan motivasi dalam proses pembelajaran.

Hu dan Adey (2010) mengungkapkan bahwa Kreativitas ilmiah (scientific creativity) merupakan jenis intelektual atau kemampuan untuk menghasilkan atau berpotensi menghasilkan suatu hasil tertentu yang orisinil atau nyata (Hu, Xiaohui, \& Shieh, 2017) dengan diiringi tujuan pemikiran tertentu menggunakan informasi yang sudah ada (Setyadin, Siahaan, \& Samsudin,2017). Sudijono (2015) mengungkapkan bahwa perubahan tingkah laku yang telah terjadi setelah melalui proses pembelajaran merupakan hasil belajar yang diinginkan.

\section{METODE PENELITIAN}

Penelitian tindakan kelas secara bersiklus yang digunakan dalam penelitian ini di XI MIPA 2 di SMAN 8 Banjarmasin. Siklus pertama dan kedua diisi dengan 2 kali pembelajaran disetiap siklusnya dan 1 kali tes.

Objek penelitian ini adalah kelas XI MIPA 2 di SMAN 8 Banjarmasin tahun ajaran 2018/2019. Seluruh berjumlah 36 orang. Penelitian ini dilaksanakan pada 01 maret - 09 April 2019. Teknik data yang digunakan dalam penelitian di SMAN 8 Banjarmasin adalah lembar observasi yang bertujuan untuk mengetahui nilai aktivitas guru, aktivitas, sikap, dan keterampilan, tes kreativitas ilmiah untuk mengukur kreativitas ilmiah dan pengetahuan.

\section{HASIL PENELITIAN DAN PEMBAHASAN Aktivitas guru}

Tujuan daripada penelitian ini yaitu meningkatkan aktivitas guru dengan model CPS yang digunakan saat pembelajaran. Aktivitas guru yang diamati yaitu (1) seperti halnya yang bisa dilakukan yang pertama guru mengucapkan salam dan berdoa sebelum dimulainya pembelajaran, (2) guru memberikan apersepsi dann menyampaikan tujuan pembelajaran, (3) guru menjelaskan tentang sintak-sintak model pembelajaran yang digunakan dengan tujuan agar mereka mengetahui dan memahaminya, (4) guru membagikan permasalahan melalui LKPD kepada masingmasing kelompok dan memberikan informasi singkat disertai dengan menyajikan permasalahan kepada peserta didik, (5) guru mengungkapkan strategi penyelesaian masalah, dan menerapkan strategi pemecahan masalah, (6) guru mendorong dialog dan diskusi dalam kelompok, (7) guru meminta peserta didiik untuk tampil menunjukkan hasil pemecahan masalah yang sudah mereka temukan dan membimbingnya bila menemui kesulitan itu, (8) guru membimbing menyimpulkan bersama tentang materi yang dipelajari, (9) guru juga memberikan tahukan informasi terkait materi yang akan dipelajari lagi pada pertemuan selanjutnya, (10) guru meutup pembelajaran dengan doa dan salam. Hasil observasi peningkatan aktivitas guru dapat dilihat pada Gambar 1 dan Gambar 2 berikut ini. 


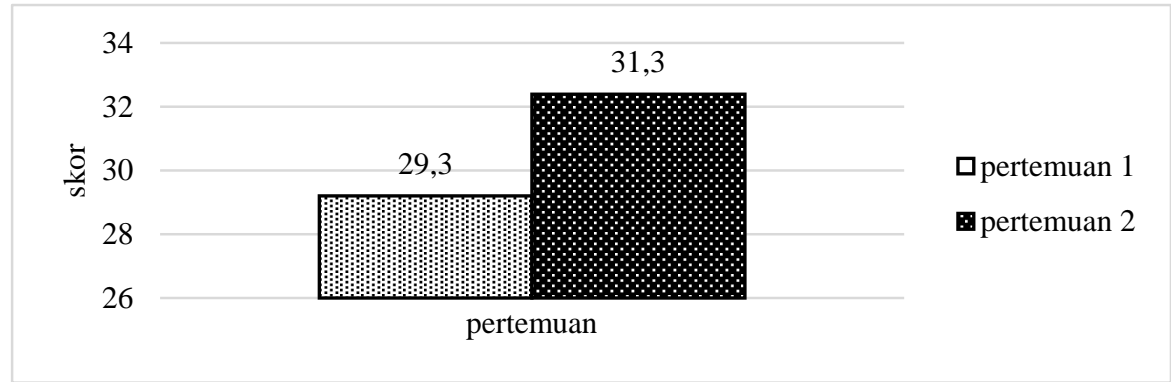

Gambar 1. Siklus I

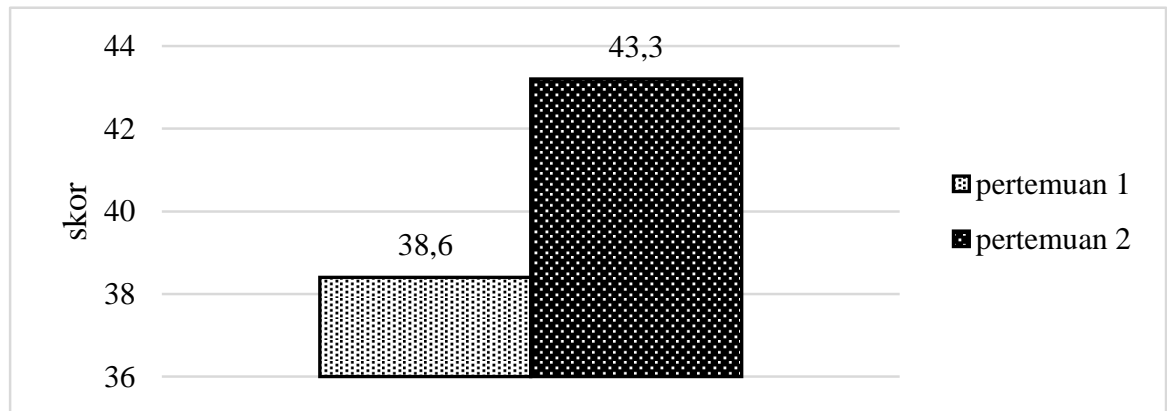

Gambar 2. Siklus II

Pelaksanaan proses belajar kurang berjalan lancar, dikarenakan aspek pada poin 4 dan poin 7 baik pertemuan pertama dan pertemuan kedua belum terlaksana maksimal. Poin 4 yang diamati yaitu "Guru membagikan LKPD kepada masingmasing kelompok dan memberikan informasi singkat disertai dengan menyajikan permasalahan kepada peserta didik" . Poin 7 yang diamati yaitu "Guru meminta peserta didik menyajikan hasiil pemecahan masalaah dan membimbingnya bila menemukan kesulitan".

Siklus I masih terdapat kekurangan dikarenakan guru masih menggunakan pembelajaran konvensional. Penelitian (Yustina, Irhansyuarna, \& Kusasi, 2015) menjelaskan bahwa menggunakan pembelajaran konvensional memperoleh kemampuan berpikir yang rendah. Siklus II, guru merefleksi. Guru bersikap lebih tegas pada siklus II sejalan dengan penelitian Azreen \& Mohamed (2014) mengungkapkan bahwa guru diharuskan lebih tegas dalam bersikap. Peningkatan aktivitas guru pada penelitian ini juga didukung oleh penelitian yang dilakukan oleh Solfitri, \& Armis (2016).

\section{Analisis Aktivitas Peserta Didik}

Aktivitas yang diamati (1) menjawab salam yang telah diucapkan guru dan berdoa sebelum memulai pembelajaran secara bersama-sama, (2) menyampaikan pendapat terhadap apersepsi, (3) memperhatikan penjelasan dari guru tentang model CPS, (4) peserta didik membentuk kelompok dan megerjakan LKPD dengan memperhatikan informasi yang disampaikan guru, (5) mengungkapkan strategi penyelesaian masalah dalam permasalahan yang tersdia didalam LKPD yang dibagikan tersebut, (6) peserta didik berdiskusi dalam kelompok, (7) menyajikan hasil pemecahan masalah, (8) menyimpulkan materi secara bersama, (9) memperhatiikan 
sedikit informasi singkat dari guru mengenai materii yang akan dipeajari pada pertemuan selanjutnya, (10) berdoa dan meenjawab salam yang diberikan guru. Pengamatan sesudah selesai prosedur belajar mengajar (Kunandar, 2011). Hasil observasi yang telah dilakukan oleeh observer dapat kita dilihat pada berikut:

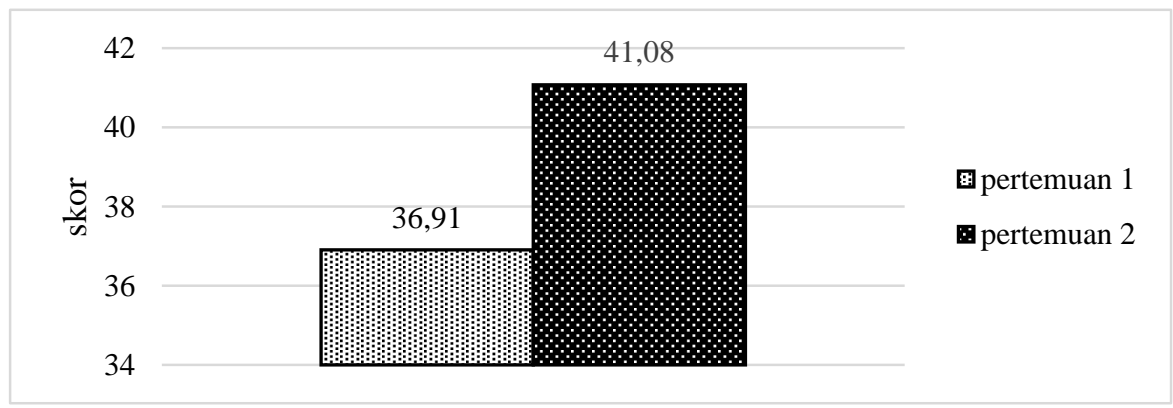

Gambar 3. Observasi pada siklus I hasill aktivitas peserta didik

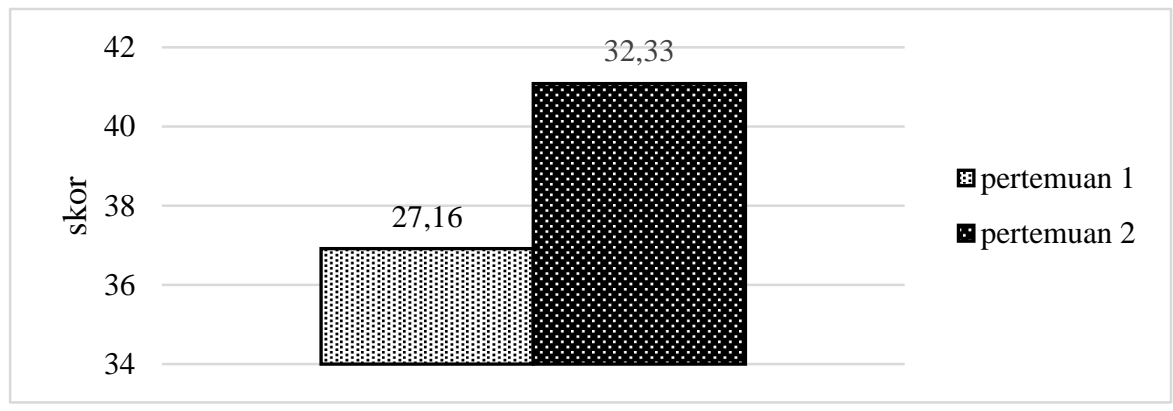

Gambar 4. Observasi pada siklus II aktivitas peserta didik

Pada pertemuan pertama disana kurang memperhatikan tentang sintak pada bagian fack finding yang mengakibatkan kurang memahami hal yang seharusnya mereka lakukan pada sintak tersebut. Yaitu "Peserta didik menemukan semua fakta yang mungkin berkaitan dengan sasaran tersebut" . Terjadi peningkatan pada pertemuan kedua, diantaranya pada aspek poin 3, 7 dan 8 hal ini dikarenakan guru melakukan perbaikan tindakan dalam proses pembelajaran.

Aspek pada poin 3 yaitu "peserta didik memprhatikan penjelasan dari guru tentang sintak-sintak (langkah-langkah) yang harus mereka lakukan pada model CPS" mengalami peningkatan dari jumlah nilai 91 menjadi 132. Aspek pada poin 7 yaitu "peserta didik menyajikan hasil pemecahan masalah" mengalami peningkatan dari jumlah nilai 95 menjadi 104. Aspek pada poin 8 yaitu "peserta didik menyimpulkan materi secara bersama" mengalami peningkatan dari jumlah nilai 90 menjadi 107.

Data di atas, menunjukkan meningkat pada siklus II. Hal ini berhubungan dengan keberhasilan perbaikkan dari kekurangan guru pada siklus I. Menurut Hosnan (2014) kegiatan belajar yang menarik ditandai dengan aktif dalam belajar, yang mana peserta didik mencatat poin-poin dari penjelasan guru dan terjadi interaksi pembelajaran antara peserta diidik dengan guru yang memberikan pembelajaran. 


\section{Analisis Sikap Peserta Didik}

Perilaku yang dinilai yaitu rasa ingin tahu, disiplin, dan bekerja sama.

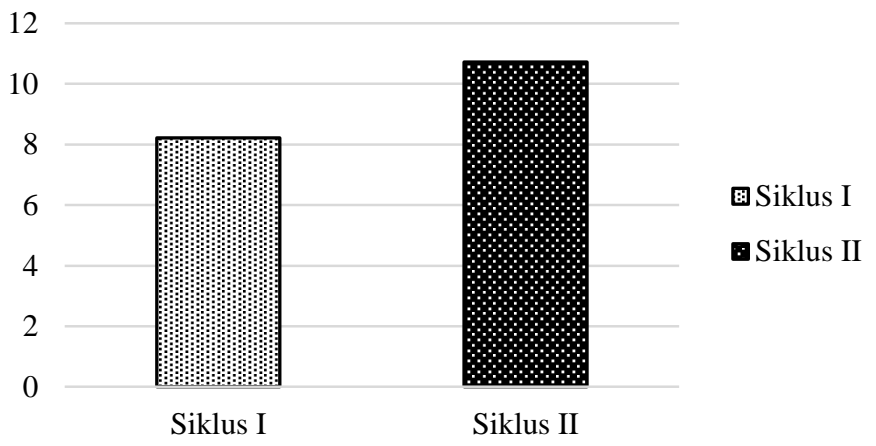

Gambar 5. Perbandingan peningkatann sikap siklus I dan siklus II

Sikap mereka meningkat pada siklus II. Menurut pendapat Winarti \& Suharto (2017) mengatakan motivasi pada awal pembelajaran dapat dimunculkan dengan menumbuhkan rasa keingintahuan dalam diri terhadap materi yang diajarkan.

\section{Analisis Keterampilan Peserta Didik}

Keterampilan dapat dinilai ketika melakukan kegiatan penyelidikan termasuk praktikum. Aspek yang dinilai adalah saat menggunakan gelas ukur untuk sampel, menggunkan pipet tetes untuk sampel, dan mengukur $\mathrm{pH}$ larutan menggunakan indikator universal.

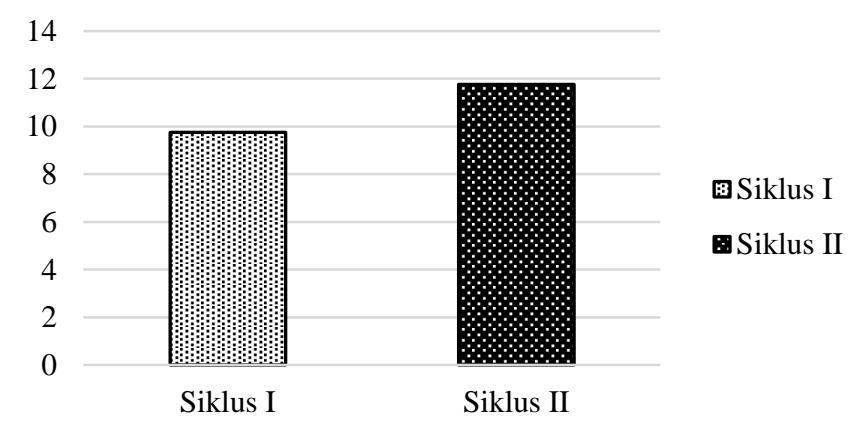

\section{Gambar 6. Peningkatan keterampilan peserta didik siklus I dan II}

Hasil penelitian Praweenya, Jaemjan \& Dachakupt (2015) mengatakan bahwa pengalaman belajar dari melihat, melakukan, mendengar dan bergerak dapat merangsang indra belajar dan mengajukan pertanyaan sehingga pemikiran lebih berkembang. 


\section{Analisis Kreativitas Ilmiah Peserta Didik}

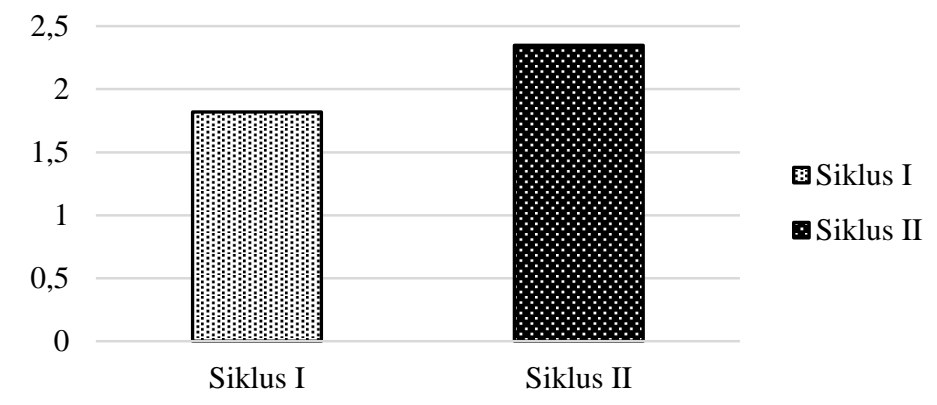

Gambar 7. Nilai kreativitas ilmiah

Siklus II meningkat dalam kriteria baik dengan nilai rata-rata 2,35. Penelitian ini sesuai dengan penelitian malisa, bakti, \& iriani (2018). Hal ini sejalan pendapat Soraya, Rusmansyah,\& Istyadji (2018).

\section{Analisis Hasil Belajar Pengetahuan Peserta Didik}

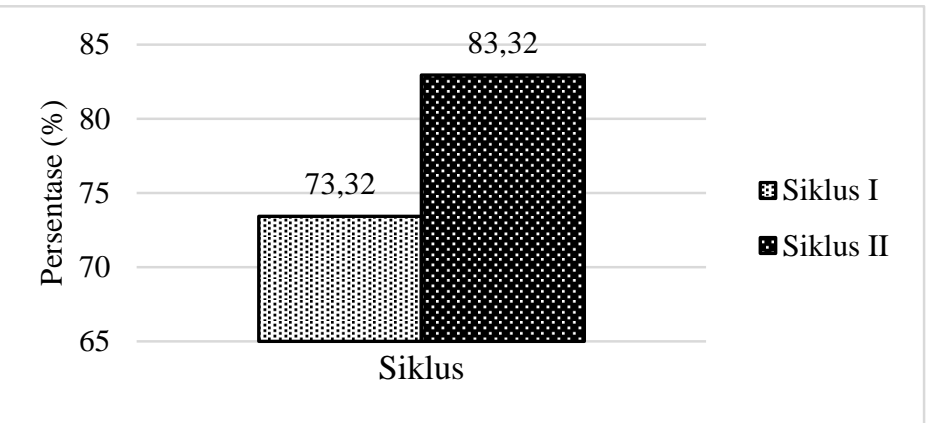

\section{Gambar 8. Perbandingan hasil belajar pengetahuan peserta didik}

Hasil belajar berada pada kategori renndah pada soal nomor 4 dan 7. Hasil jawaban tes pengetahuan untuk soal nomor 4 pada gambar 9.

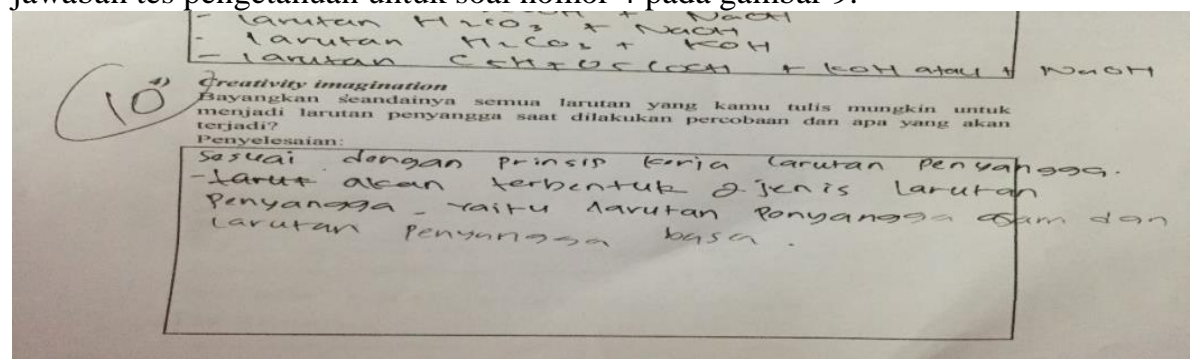

Gambar 9. Jawaban tes pengetahuan peserta didik soal nomor 4 


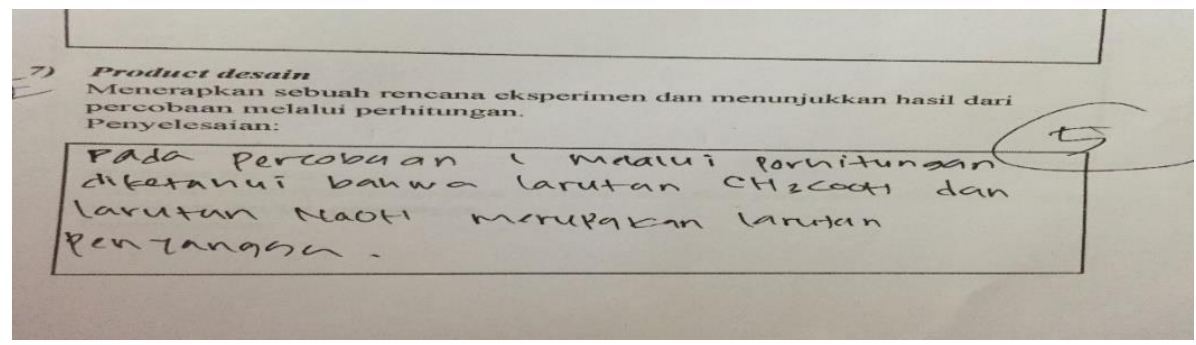

Gambar 10. Jawaban tes pengetahuan peserta didik soal nomor 7

Soal tes nomor 4 yaitu "peserta didik dapat membayangkan seandainya semua larutan mungkin untuk menjadi larutan penyangga", jawaban yang diharapkan "Larutan penyangga berperan juga untuk mempertahankan nilai pH nya pada kisarannya. Jika kedalam air murni dan larutan penyangga $\mathrm{CH}_{3} \mathrm{COOH} / \mathrm{CH}_{3} \mathrm{COO}^{-}$ ditambahkan sedikit basa kuat $\mathrm{NaOH} \mathrm{0,1} \mathrm{M} \mathrm{padaa} \mathrm{masing-masing} \mathrm{Varutan,} \mathrm{maka}$ apa yang akan terjadii ? Soal tes pada nomor 7 yaitu "peserta didik menerapkan sebuah rencana eksperimen dan menunjukkan hasil dari percobaan melalui perhitungan" dengan jawaban yang diharapkan yaitu "pada percobaan 1 melalui perhitungan diketahui bahwa larutan $\mathrm{CH}_{3} \mathrm{COOH}$ dan larutann $\mathrm{NaOH}$ merupakan larutan penyangga.

Penelitian Herbert (2017) yang menyatakan bahwa keberhasilan peserta didik dalam memecahkan per masalahan dalam kegiatan pembelajaran dipengaruhi oleh aktivitas pengajar. Meningkatnya ketuntasan hasil belajar pengetahuan yang didapat peserta didik dalam penelitian ini sesuai dengan hasil penelitian Hartini, Kusasi, \& Iriani (2017). Selain itu, penelitian Rinawati \& Saadi (2016) serta penelitian Sakaningsih dan Negara (2014) dan Setiawan, Suharto, \& Iriani (2017) pada penelitian penerapan strategi pembelajaran POE untuk meningkatkan hasil belajar.

\section{SIMPULAN}

Penggunaan model pembelajaran Creative Problem Solving (CPS) ini ternyata dapat meningkatkan hasil dari kreativitas ilmiah, dan hasil belajar. Selain itu, juga dapat meningkatkan aktivitas guru dan siswa pada penggunaan model pembelajaran ini.

\section{DAFTAR RUJUKAN}

Azreen, R., \& Mohamed, M. (2014). The Perception of Critical Thinking and Problem Solving Skill Among Malaysian Undergraduate Students. Journal Social and Behaviorall Science, I(172), 725-732.

Hartantia, R. M., Hayus, E. S., \& Saputro, A. N. (2013). Penerapan Model Creative Problem Solving (CPS) untuk Meningkatkan Minat dan Hasil Belajar Kimia pada Materi Pokok Termokimia Siswa Kelas XI. IA2 SMA Negeri Colomadu Tahun Pelajaran 2012/2013. Jurnal Pendidikan Kimia (JPK), 100-109.

Hartini, E. M., Kusasi, M., \& Iriani, R. (2017). Meningkatkan Keterampilan Proses Sains dan Hasil Belajar Melalui Model Problem Solving dengan Pendekatan Saintifik pada Materi Hidrolisis Garam. Journal of Chemistry And Education. 1 (1): 37-45.

Herbert, N. (2017). Using Critical Thinking Teaching Methods to Increase Student Success. Journal of Teaching and Learning in Higher Education, 29(1), 1731.

Hosnan, M. (2014). Pendekatan Saintifik dan Kontektual dalam Pembelajaran Abad 21. Bogor: Gualia Indonesia. 
Hu, R., Xiaohui, S., \& Shieh, C.-J. (2017). A Study on the Application of Creative Problem Solving Teaching to Statistics Teaching. EURASIA Journal of Mathematics Science and Technology Education, 45 (8), 3139-3149.

Hu, W. \& Adey, P. (2010). A scientific creativity test for secondary school students. International Journal of Science Education, 24 (4), 389-403.

Kunandar. (2011). Penelitian Tindakan Kelas Sebagai Pengembangan Profesi Guru Edisi Revisi. Jakarta: PT Rajawali Pers.

Malisa, S., Bakti, I.,\& Iriani,R.(2018). Model Pembelajaran Creative Problem Solving (CPS) Untuk Meningkatkan Hasil Belajar dan Kemampuan Berfikir Kreatif Siswa. Jurnal Vidya Karya, 33(1),1-20.

Praweenya, S., Jaemjan, S., \& Dachakupt, P. (2015). Virtual Field Trips With Inquiry Learning and Critical Thinking Process : a Learning Model to Enhance Student Science Learning Outcomes. Procedla-Social and Behavioral Sciences, 1(197), 143-155.

Rinawati, \& Saadi, P. (2016). Meningkatkan Kemampuan Berfikir Kreatif dan Hasil Belajar Siswa Melalui Model Pembelajaran Creative Problem Solving (CPS) Pada Materi Larutan Penyangga. Jurnal Inovasi Pendidikan Sains, 127-134.

Ristiyani, E., \& Bahriah, E. S. (2016). Analisis kesulitan belajar kimia siswa di SMAN $\mathrm{X}$ Kota Tangerang Selatan. JPPI, II(1), 18-29.

Sakaningsih, N. M., Asri, I. G. A. A. S. A., \& Negara, I. G. A. O. (2014). Model Pembelajaran Creative Problem Solving Berbasis Reinforcement Berpengaruh Terhada Hasil Belajar Pkn Siswa Kelas V SDN 18 Dangin Puri. Jurnal Mimbar PGSD Pendidikan Ganesha Jurusan PGSD, 1-10.

Setiawan, R., Suharto, B., \& Iriani, R. (2017). Penerapan Strategi Pembelajaran POE (Predict-Observe-Explain) untuk Meningkatkan Hasil Belajar dan Keterampilan Berpikir Kritis Siswa pada Materi Larutan Penyangga. Journal of Chemistry And Education, 1(1), 143-150.

Setyadin, A.H., Siahan,P.,\& Samsudin,A. (2017). Desain tes kreativtas ilmiah berbasis HU dan ADEY dalam matei kebumian. Jurnal Wahana Pendidikan Fisika, 1(2), 56-62.

Soraya, N., Rusmansyah, \& Istyadi, M. (2018). Pengaruh Model Think Pair ShareProblem Solving Terhadap Kemampuan Berpikir Kritis dan Self-Efficacy Siswa. Jurnal Inovasi Pendidikan Sains, 9(1), 70-75.

Sudijono, A. (2015). Pengantar Evaluasi Pendidikan. Jakarta: Rajawali Pers.

Susilowati, E., \& Harjani, T. (2013). Kimia 1 untuk kelas X SMA dan MA kelompok peminatan matematika dan ilmu-ilmu alam. Solo: PT. Wangsa Jatra Lestari.

Syamsu, S. A., Yunus, M., \& Masri, M. (2016). Penerapan Model Creative Problem Solving (CPS) untuk Meningkatkan Kemampuan Berpikir Kreatif Kelas XI MIA 1 SMA Negeri 1 Bulukumba (Studi pada Materi Pokok Laju Reaksi). Jurnal Chemica, 2(4), 63-74.

Winarti, E., \& Suharto, B. (2017). Meningkatkan Motivasi dan Hasil Belajar Melalui Model Pembelajaran Audiotory, Intellectually, Repretition pada Materi Larutan Penyangga di Kelas XI IPA SMA Muhammadiyah 1 Banjarmasin. Journal of Chemistry and Education, I(1), 28-36.

Yustina, S., Irhansyuarna, Y., \& Kusasi, M. (2015). Penerapan Model Pembelajaran Problem Solving Terhadap Kemampuan Berpikir Kritis Siswa Pada Materi Koloid Kelas XI IPA SMA Negeri 4 Banjarmasin. Jurnal Inovasi Pendidikan Sains, $V I(2)$. 